\title{
The Impression of Job Training and Work Motivation Effect at PT. Aksata Satya Pratama Jakarta
}

\author{
JuwitaRamadani Fitria $^{1}$, Aria Mulyapradana*2, Mujibul Hakim³ ${ }^{3}$, S.Thoriqul Huda ${ }^{4}$ \\ ${ }^{1}$ Management Study Program, UniversitasPamulang, South Tangerang, Banten, Indonesia. \\ ${ }^{2}$ Office Administration Study Program, PoliteknikPusmanu, Pekalongan, Central Java, Indonesia. \\ ${ }^{3}$ Information Technology Study Program, ITS NU Pekalongan, Central Java, Indonesia. \\ ${ }^{4}$ CommunicationScience Study Program, UniversitasSelamat Sri Kendal, Central Java, Indonesia. \\ Corresponding Author: \\ Email: ariamulyapradana@gmail.com
}

\begin{abstract}
.
This research intends to determine the effect of job training and work motivation on performance at PT. Aksata Satya Pratama. To produce quality employees and good performance, companies need to pay attention to increasing knowledge by providing job training. The job training program at PT. Aksata Satya Pratama is still not optimal so that it has an impact on decreased employee performance. Respondents in this research were 40 people and used census techniques. Testing data in this research used validity test, reliability test, classic assumption test (multicollinearity test), multiple linear regression test and hypothesis testing and data analysis in this research using SPSS version 19 program. The results of the research show that job training variables have a negative value ( $H_{1}$ is rejected) and work motivation has a positive value ( $\mathrm{H}_{2}$ is accepted). This means that the training variable has no influence on employee performance and work motivation has an influence on employee performance by $67.1 \%$. So, it is stated that job training has no significant effect on employee performance while work motivation has a significant effect on employee performance. In this research, researchers concluded that employee performance will increase supported by employee motivation by factors of work results that are recognized as proven by employees being able to complete various kinds of work.
\end{abstract}

Keywords: Job Training, Work Motivation, Performance, Employees

\section{T. INTRODUCTION}

The need to get knowledge is something that should be owned by everyone, along with the changing times of science, it is growing rapidly. Having knowledge could be useful for oneself and the environment. To reach the goal of a company effectively and efficiently, employees need to increase their knowledge with human resource development programs, namely job training. With the training program provided to employees, it can improve the quality of employees so that it has an impact on employee work performance and the achievement of company goals. This is reinforced by research conducted by Yusuf WildanSetiyadi\& Sri Wartini (2016) saying that the variable quality of work life has a positive effect on job satisfaction; work quality variable has a positive effect on employees task; Job satisfaction variable has a positive effect on employees task and the quality of work life variable has an indirect effect through job satisfaction on employees task.

Training programs made by the company for employees are a necessity that must be met in order to obtain good employee quality and performance. The training program is made based on the needs of the company by means of an inventory of the needs of employees or evaluating employees task against the deficiencies of these employees. According to Malayu S.P Hasibuan (Supomo, 2018), the training process for improving the technical skills and work morale of operational employees is in accordance with the needs of their duties. Similarly expressed by Simamora (Baharuddin et al., 2015) explained that training describes a learning process that involves acquiring skills, concepts, rules or attitudes to improve employees task. 
With good human resource management and developing the abilities possessed by each employee, it can be beneficial for both employees and the company so that the expected goals are achieved effectively and efficiently. The goals of employees being given training (Widodo, 2015) include improving performance, updating employee skills, avoiding managerial obsolescence, solving organizational problems, preparing for promotion and managerial succession and meeting personal satisfaction needs. The same thing was expressed by Suparyadi (2015) where the objectives of the training include increasing productivity, increasing effectiveness and efficiency and increasing competitiveness. Training indicators (Aruan, 2013) include the material needed, the methods used, the ability of training instructors, training facilities and facilities, training participants.

Increasing the knowledge and abilities possessed by employees is a supporting factor in the creation of employee motivation because with the knowledge and abilities employees can work optimally so that the work they do can be of quality. In addition, the training program provided to employees is a form of company concern for its employees. The attention given indirectly has an impact on increasing employee motivation and employees task in the company. According to research conducted by Patricia M. Sahanggamu\&Silvya L. Mandey (2014), it shows that job training, motivation and work discipline together have an effect on an employees task.

Motivation is an activity and support in humans that can cause, direct and organize behaviour. As for the elements of work motivation, including the direction of behaviour, level of effort and level of persistence (Setiawan\&Mulyapradana, 2019). Meanwhile, according to Wexley\&Yuld (Sutrisno, 2016), motivation is a gift or the arising of a motive or it can also be interpreted as a matter or condition to be a motive.

Aspects that affect individual work motivation in carrying out work activities are internal factors and external factors from oneself (Riyadi\&Mulyapradana, 2017). The same thing was expressed by Edy Sutrisno (Sutrisno, 2016), there are two aspects that influence motivation, including internal factors and external factors. Internal factors consist of the desire to be alive, the desire to get respect, the desire to gain recognition and the desire to rule. Meanwhile, external factors consist of working environment conditions, adequate compensation, good supervision, job security, status and responsibilities and flexible regulations.

PT. Aksata Satya Pratama is a new developing company. In order to continue to grow and win business competition with several other companies, the company needs to pay attention to human resource management because good employee management will affect healthy company performance and vice versa if you don't pay attention to employees it will have an impact on the company's performance so that the goals cannot be achieved. has been set by the company. Based on the results of interviews conducted by researchers with respondents, it was revealed that the training program made by the company was still not optimal so that there were some employees who did not have renewal or increase in knowledge, especially related to their work. This results in decreased employees tasks because some tasks are not completed in accordance with the specified time.

Performance Assessment called actual performance is the actual performance or achievement achieved by a person in carrying out tasks in accordance with the responsibilities given to him (Elshifa, 2018). According to Mangkunegara said that performance is the result obtained by employees both in quantity and quality for carrying out the duties and responsibilities given by the company (Elshifa et al., 2020). So, an employee 's task really determines how a job process can run well in order to achieve company goals, namely by placing employees according to expertise, work discipline, job satisfaction, management systems, motivation and compensation (Hakim \&Fanani, 2019). Performance indicators in this research are quality, quantity, timeliness, ability and responsibility for work (Elshifa, 2018).

This phenomenon is a topic that will be studied more deeply by researchers with the title of the effect of job training and work motivation on employee 's tasks at PT. Aksata Satya Pratama Jakarta. The purpose of this research is to see whether or not there is an effect of job training and work motivation on performance at PT. Aksata Satya Pratama Jakarta and the limitations of the problems in 
this research are related to job training, work motivation and employee 's tasks at PT. Aksata Satya Pratama Jakarta.

\section{METHODS}

This research used quantitative descriptive and survey methods conducted (Bahasoan et al., 2020). The sampling technique used in this research is census sampling because the population in this research object is below 100 employees, namely 40 employees, so in this study the researchers distributed questionnaires to 40 respondents in this company. To study the data in research, the SPSS version 19 program was used. To test the data in this research using:

a. validity test, is to show the accuracy and accuracy of a measuring instrument in performing its measuring function(Khaeruman\&Tabroni, 2020).

b. Reliability tes aim to measure the instrument so that it can be trusted and produce reliable data too(Khaeruman\&Tabroni, 2020).

c. Multiple linear regression analysis, analysis to determine the direction of the influence variable on the dependent variable (Khaeruman\&Tabroni, 2020).

d. Classic assumption test (multicollinearity test)

e. Hypothesis testing.

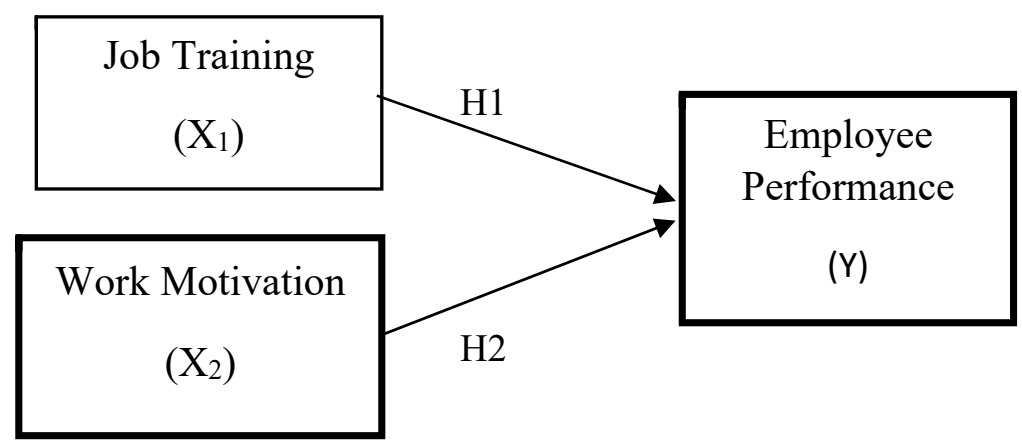

Fig.1. Framework

Ho: There is a positive and significant influence between Job Training $\left(\mathrm{X}_{1}\right)$ and Work Motivation $\left(\mathrm{X}_{2}\right)$ on Employee 's task (Y) at PT. Aksata Satya Pratama Jakarta.

Ha: There is no positive and significant influence between Job Training $\left(\mathrm{X}_{1}\right)$ and Work Motivation $\left(\mathrm{X}_{2}\right)$ on Employee 's task (Y) at PT. Aksata Satya Pratama Jakarta.

\section{RESULT AND DISCUSSION}

Based on the results of the data collection, the research results obtained a representation of the research results, namely the number of respondents in this research was 40 respondents consisting of 18 male respondents $(45 \%)$ and 22 female respondents $(55 \%)$. The ages of respondents in this research varied, including 28 respondents aged 19-25 years (70\%), 4 respondents aged 26-30 years $(10 \%), 5$ respondents aged 31-35 years $(12,5 \%), 1$ respondent $(2.5 \%)$ aged $36-40$ years and 2 respondents $(5 \%)$ over 41 years old. The education level of these respondents, namely the level of SMA / equivalent education amounted to 16 respondents (40\%), D3 amounted to 8 respondents (20\%), S1 / D4 amounted to 6 respondents (15\%) and S2 education level was 10 respondents $(25 \%)$.

Table 1. Testing Instruments and Validity Test

\begin{tabular}{|c|c|c|c|c|c|}
\hline Variable & KMO & Sig. & Item & $\begin{array}{c}\text { Loading } \\
\text { Factor }\end{array}$ & Information \\
\hline \multirow{4}{*}{ Job Training } & \multirow{4}{*}{0,839} & \multirow{4}{*}{0,000} & $\mathrm{X} 1.1$ & 0.859 & Valid \\
\cline { 4 - 6 } & & & $\mathrm{X} 1.2$ & 0.810 & Valid \\
\cline { 4 - 6 } & & $\mathrm{X} 1.3$ & 0.885 & Valid \\
\cline { 3 - 6 } & & $\mathrm{X} 1.4$ & 0.873 & Valid \\
\hline
\end{tabular}




\begin{tabular}{|c|c|c|c|c|c|}
\hline \multirow[t]{2}{*}{$\left(X_{1}\right)$} & & & $\mathrm{X} 1.5$ & 0.877 & Valid \\
\hline & & & X1.6 & 0.872 & Valid \\
\hline \multirow{9}{*}{$\begin{array}{l}\text { Work Motivation } \\
\qquad\left(\mathrm{X}_{2}\right)\end{array}$} & \multirow{9}{*}{0,825} & \multirow{9}{*}{0,000} & $\mathrm{X} 2.1$ & 0.755 & Valid \\
\hline & & & $\mathrm{X} 2.2$ & 0.801 & Valid \\
\hline & & & $\mathrm{X} 2.3$ & 0.770 & Valid \\
\hline & & & X2.4 & 0.895 & Valid \\
\hline & & & $\mathrm{X} 2.5$ & 0.846 & Valid \\
\hline & & & X2.6 & 0.806 & Valid \\
\hline & & & $\mathrm{X} 2.7$ & 0.759 & Valid \\
\hline & & & $\mathrm{X} 2.8$ & 0.881 & Valid \\
\hline & & & X2.9 & 0.843 & Valid \\
\hline \multirow{5}{*}{$\begin{array}{c}\text { Employee 's task } \\
\text { (Y) }\end{array}$} & \multirow{5}{*}{0,747} & \multirow{5}{*}{0,000} & Y1 & 0.806 & Valid \\
\hline & & & Y2 & 0.852 & Valid \\
\hline & & & Y3 & 0.829 & Valid \\
\hline & & & Y4 & 0.788 & Valid \\
\hline & & & Y5 & 0.699 & Valid \\
\hline
\end{tabular}

Source: Primary data processed by SPSS 19

The validity test in this research uses a factor analyst, the first step for researchers to do the KMO test to see whether an item is valid or not in a distributed questionnaire in order to see the loading factor value. If the loading factor value is $>0.5$, it is said to be valid. For the variables in this research, the KMO value is obtained as follows: job training $\left(\mathrm{X}_{1}\right)$ of 0.839 , work motivation $\left(\mathrm{X}_{2}\right)$ of 0.825 and satisfaction $(\mathrm{Y})$ of 0.747 .

Based on in table 1 that the variables of use of job training, work motivation and performance have a KMO greater than 0.5 and a sig less than 0.05 , this focuses that the criteria for the adequacy of the sample from this research have been met. For the indicators in this research, the loading factor value $>0.5$ indicates that all indicators are declared valid. In this answered that the training facilities were good to support training activities, $89 \%$ of employees felt motivated by the recognized results of their work and the employee 's task was good with $85 \%$ of employees able to complete various kinds of work. However, the training method in companies using lectures and work practices is considered to be less than the maximum, only $81 \%$, employee morale in supporting the achievement of job duties is still low, only $75 \%$ and employee responsibility for the work given by the boss is only $69 \%$.

Table 2. Reliability Test

\begin{tabular}{|l|c|}
\hline \multicolumn{1}{|c|}{ Variabel } & $\begin{array}{c}\text { Cronbach's } \\
\text { Alpha }\end{array}$ \\
\hline Job Training &, 970 \\
\hline Work Motivation &, 969 \\
\hline Employee 's task &, 970 \\
\hline
\end{tabular}

Source: Primary data processed by SPSS 19

Table 2 above states that Cronbach's alpha must be more than 0.7, meaning that the data is reliable and Cronbach alpha per item must be below Cronbach's alpha total data to be continued for further testing. To see the reliability in this research, the Cronbach alpha value $>0.7$ is said to be reliable. In this research, the value of Cronbach alpha, namely: job training $\left(\mathrm{X}_{1}\right)$, the value of Cronbach alpha is 0.970 , so this variable is said to be reliable, the work motivation variable $\left(\mathrm{X}_{2}\right)$ Cronbach alpha has a value of 0.969 so this variable is said to be valid and the performance variable (Y) Cronbach alpha has 
a value amounting to 0.970 it is said to be valid. Then the Cronbach alpha value in this research is more than 0.7 and is declared reliable.

Table 3. Classical Assumption Test (Multicollinearity Test)

\section{Correlations}

\begin{tabular}{|ll|r|r|r|}
\hline & & Employee 's task & Job Training & $\begin{array}{c}\text { Work } \\
\text { Motivation }\end{array}$ \\
\hline $\begin{array}{l}\text { Pearson } \\
\text { Correlation }\end{array}$ & Employee 's task & 1,000 &, 477 &, 639 \\
& Job Training &, 477 & 1,000 &, 772 \\
& Work Motivation &, 639 &, 772 & 1,000 \\
\hline Sig. (1-tailed) & Employee 's task & &, 001 &, 000 \\
& Job Training &, 001 & &, 000 \\
& Work Motivation &, 000 &, 000 & 40 \\
\hline N & Employee 's task & 40 & 40 & 40 \\
& Job Training & 40 & 40 & 40 \\
\hline
\end{tabular}

Source: Primary data processed by SPSS 19

The result of the correlation between the independent variables $X_{1}$ and $X_{2}$ is $r=0.772$. Because the value of 0.772 is less than 0.8 , multicollinearity symptoms are not detected, from the results above there is no multicollinearity problem so the test results are said to be reliable or reliable. Then the value of the partial regression coefficient is said to be reliable and robust or immune to changes that occur in other variables in the multiple regression model.

Table 4. Multiple Linear Regression Test and Hypothesis Testing

\begin{tabular}{|l|c|c|c|c|}
\hline \multicolumn{1}{|c|}{ Model } & $\begin{array}{c}\text { Adjusted } \\
\text { R Square }\end{array}$ & $\begin{array}{c}\text { Stand. } \\
\text { Coef }\end{array}$ & Sig. & Information \\
\cline { 1 - 3 } $\begin{array}{l}\text { Job Training on } \\
\text { Performance }\end{array}$ & 0,377 & $-0,041$ & 0,838 & rejected \\
\cline { 1 - 1 } $\begin{array}{l}\text { Work Motivation on } \\
\text { Performance }\end{array}$ & & 0,671 & 0,002 & accepted \\
\hline
\end{tabular}

Source: Primary data processed by SPSS 19

$$
\mathrm{Y} 1=-0.041 \mathrm{X} 1+0.671 \mathrm{X} 2
$$

The results of the above equation show that the job training variable has a negative value $\left(\mathrm{H}_{1}\right.$ is rejected) and work motivation has a positive value $\left(\mathrm{H}_{2}\right.$ is accepted), meaning that the better training does not affect employee 's task and employee work motivation affects performance. The results of this research show that work motivation affects performance as much as $67.1 \%$.

\section{CONCLUSION}

This research was conducted to examine the effect of job training variables and work motivation variables on performance variables at PT. Aksata Satya Pratama Jakarta shows that job 
training is not able to influence $\mathrm{H}_{1}$ performance and is rejected, this can be seen from the Sig. value. is greater than 0.05 , namely 0.838 and work motivation is able to influence $\mathrm{H}_{2}$ performance is accepted, it can be seen from the Sig value. less than 0.05 which is 0.02 . Job training is proven to have no significant effect on employee performance, while work motivation has a significant effect on employee performance. In this study, researchers concluded that employee performance will increase supported by employee motivation by factors of work results that are recognized as proven by employees being able to complete various kinds of work. To optimize the job training program, it is recommended that the company be able to analyse the needs needed by employees so that the training is carried out on target so that it can help achieve the goals of the company.

\section{ACKNOWLEDGMENTS}

The authors are grateful to CEO PT. Aksata Satya Pratama Jakarta and employees who were involved in this research at PT. Aksata Satya Pratama Jakarta and the parties involved in this research.

\section{REFERENCE}

[1] Aruan, D. A. (2013). PengaruhPelatihanKerja dan MotivasiTerhadapKinerjaKaryawan PT. Sucofindo (Persero) Surabaya. JurnalIImuManajemen.

[2] Baharuddin, A., Alhabsyi, T., \&Utami, H. N. (2015). PengaruhPelatihan, Kompensasi dan DisiplinKerjaTerhadapPrestasiKerjaKaryawan (Studi Pada Kantor PT. PLN (Persero) Area Pelayanan dan Jaringan Malang). Jurnal Profit.

[3] Bahasoan, A., Ayuandiani, W., Mukhram, M., \&Rahmat, A. (2020). Effectiveness of Online Learning in Pandemic Covid-19. International Journal of Science, Technology \& Management, 1(2), 100-106. https://doi.org/https://doi.org/10.46729/ijstm.v1i2.30

[4] Elshifa, A. (2018). Pengaruh Leader Member Exchange (LMX) dan Komitmen Organisasi terhadap Kinerja KaryawandenganMediasi Organizational Citizenship Behavior (OCB) (Studi Kasus pada Karyawan KospinJasa Pekalongan).Ecomomicus, 9(1), 25-39.

[5] Elshifa, A., Anjarini, A. D., Kharis, A. J., \&Mulyapradana, A. (2020). Pengaruh Keterlibatan Kerja dan OrientasiBelajarterhadapKinerjaKaryawandenganMediasiKompetensi. Jesya (Jurnal Ekonomi\& Ekonomi Syariah). https://doi.org/10.36778/jesya.v3i2.183

[6] Hakim, M., \&Fanani, R. (2019). AnalisisKinerjaKaryawanStudiKasus PT. ReycomDokumenSolusi. Jurnal Dinamika Ekonomi Dan Bisnis, 16(1), 1-16. https://doi.org/https://doi.org/10.34001/jdeb.v16i1.953

[7] Khaeruman, \&Tabroni. (2020). Performance Improvement through Skills and Work Experience at the Population and Civil Registration Office of Serang Regency. International Journal of Science, Technology \& Management, 1 (3), 209-219. https://doi.org/https://doi.org/10.46729/ijstm.v1i3.39

[8] Riyadi, S., \&Mulyapradana, A. (2017). PengaruhMotivasiKerjaTerhadapKinerja Guru RadhatulAtfal di Kota Pekalongan. JurnalLitbang Kota Pekalongan.

[9] Sahangggamu, P., \&Mandey, S. (2014). PengaruhPelatihanKerja, Motivasi, dan DisiplinKerjaTerhadap Kinerja Karyawan Pada PT. BANK PERKREDITAN RAKYAT DANA RAYA. Jurnal Riset Ekonomi, Manajemen, Bisnis Dan Akuntansi, 2(4), 514-523. https://doi.org/10.35794/emba.v2i4.6359

[10] Setiawan, S., \&Mulyapradana, A. (2019). Peran Work Motivation SebagaiVariabel Intervening PengaruhInstrinsic Reward, Supervision of Work \&Statisfaction of Compensation Terhadap Employee Performance (Studi pada Koperasi Kota Pekalongan).Jesya (JurnalEkonomi\&Ekonomi Syariah),2(1), $115-125$.

[11] Setiyadi, Y. W., \&Wartini, S. (2016). Pengaruh Kualitas Kehidupan Kerja terhadap Kinerja Karyawan dengan Kepuasan Kerja sebagai Variabel Intervening. Management Analysis Journal, 5(4), 315-324. https://doi.org/10.15294/maj.v5i4.12306

[12] Suparyadi. (2015). ManajemenSumberDayaManusia (P. Christian (ed.); 1st ed.). Andi.

[13] Supomo, R. (2018). PengantarManajemen (1st ed.). PenerbitYramaWidya.

[14] Sutrisno, E. (2016). ManajemenSumberDayaManusia (1st ed.). Kencana.

[15] Widodo, S. E. (2015). ManajemenPengembanganSumberDayaManusia (1st ed.). PustakaPelajar 